\title{
Effect of Amount of Concentrate Offered in Automatic Milking Systems on Milking Frequency, Feeding Behavior, and Milk Production of Dairy Cattle Consuming High Amounts of Corn Silage
}

\author{
A. Bach, ${ }^{*} \dagger^{1}$ C. Iglesias, $\neq$ S. Calsamiglia, $\S$ and M. Devant $†$ \\ *Institució Catalana de Recerca i Estudis Avançats, 08010 Barcelona, Spain \\ †Grup de Recerca en Nutrició, Maneig, i Benestar Animal, Institut de Recerca i Tecnologia Agroalimentàries-Unitat de Remugants, \\ 08140 Caldes de Montbui, Spain \\ ¥SEMEGA Diputació de Girona, 17121 Girona, Spain \\ §Grup de Recerca en Nutrició, Maneig, i Benestar Animal, Universitat Autònoma de Barcelona, 08193 Bellaterra, Spain
}

\begin{abstract}
The objective was to evaluate whether the amount of concentrate offered in an automatic milking systems (AMS) would modify milking frequency, feeding behavior, and milk production. One hundred fifteen lactating cows were used in a cross-over design with 2 periods of $90 \mathrm{~d}$ each and 2 treatments: low concentrate (LC; up to $3 \mathrm{~kg} / \mathrm{d}$ of concentrate at the AMS) or high concentrate $(\mathrm{HC}$; up to $8 \mathrm{~kg} / \mathrm{d}$ of concentrate at the AMS). Cows were evenly distributed in 2 symmetrical pens, each containing $1 \mathrm{AMS}$ and about 50 cows at any given time. All cows received the same total ration (28\% corn silage, $1.67 \mathrm{Mcal}$ of net energy for lactation/ $\mathrm{kg}, 16.5 \%$ crude protein, DM basis), but a different amount of concentrate from this ration was offered at the AMS depending on treatment. The concentrate at the AMS had the same composition in both treatments. Cows were fetched when time elapsed, because last milking was greater than $12 \mathrm{~h}$. The amount of concentrate offered at the AMS was proportional to the time elapsed since last visit (125 and $333 \mathrm{~g} / \mathrm{h}$ for LC and $\mathrm{HC}$, respectively). Milk production, total number of daily milkings, number of cows fetched, or number of voluntary milkings were not affected by treatments. The consumption of basal ration was greater in LC than in $\mathrm{HC}$, but this difference was compensated by a greater consumption of concentrate at the AMS in HC than LC cows. Total dry matter intake tended to be lower, therefore, in HC than in LC cows. Eating rate of the basal ration was greater in $\mathrm{LC}$ than in $\mathrm{HC}$, but the total amount of time that cows devoted to eat was similar between treatments. Offering high amounts of concentrate to the AMS feeding a basal ration rich in corn silage did not diminish the need
\end{abstract}

Received May 7, 2007.

Accepted July 21, 2007

${ }^{1}$ Corresponding author: alex.bach@irta.es for fetching cows and did not increase the number of daily milkings nor milk production.

Key words: automatic milking, concentrate, behavior

\section{INTRODUCTION}

The number of dairy enterprises with automatic milking systems (AMS) has been steadily growing in Europe during the last years. One of the most common reasons for producers to move toward AMS is the expectation of a decreased need for labor (Hogeveen et al., 2004). Erdman and Varner (1995) compiled data from several studies on milking frequency and concluded that increasing milking frequency had a fixed positive effect on milk production $(3.5 \mathrm{~kg} / \mathrm{d}$ throughout the lactation) independently of milk production level. Therefore, AMS are expected to increase milking frequency, and this should have a positive effect on milk production (Wagner-Storch and Palmer, 2003), although improving milk yield is not the first priority of AMS owners (Hogeveen et al., 2004).

In most occasions, enterprises with AMS cannot decrease labor needs, because cows must be fetched to attain at least 2 milkings per day. Furthermore, the potential increase in milk frequency does not always result in increased milk production, especially in primiparous cows (Speroni et al., 2006). On the other hand, AMS result in greater variation in milking intervals than those obtained with conventional milking parlors. Cows do not visit the AMS the same number of times nor at the same time of the day along their lactation, forcing the udders to store different amounts of milk depending on regularity of milking intervals. Irregular milkings (or visits to the AMS) have been shown to impair milk production, especially in multiparous cows (Bach and Busto, 2005).

To improve the number of visits and decrease the need for labor and variation in milking intervals, the AMS manufacturers frequently recommend offering 
high amounts of concentrate in the AMS. However, there is no scientific evidence that this practice is efficient (Halachmi et al., 2005). Furthermore, there are no studies that quantify the effect of offering different quantities of concentrate at the AMS on milking attendance and also on milk production and total feed intake. The objective of this study was to evaluate the effects of feeding different amounts of concentrate at the AMS on milking frequency, feeding behavior, and milk production of dairy cattle.

\section{MATERIALS AND METHODS}

\section{Animals and Treatments}

A total of 115 lactating Holstein dairy cows (DIM $191 \pm 2.13$; 69 primiparous, 46 multiparous) were used over a period of $7 \mathrm{mo}$. All cows were kept at the experimental research farm of the Institut de Recerca i Tecnologia Agroalimentàries in Monells (Girona, Spain) in loose housing conditions evenly distributed in 2 symmetrical pens, each containing 28 feeding places, 2 waterers $(200 \times 60 \mathrm{~cm}$ and $140 \times 45 \mathrm{~cm})$, and a robotic milking unit. Cows were on straw bedding (replaced every 2 d) and milked with an AMS (VMS, DeLaval, Tumba, Sweden). Animals were maintained and handled under the supervision of the Animal Care Committee of the Institut de Recerca i Tecnologia Agroalimentàries. All cows had free access to the AMS 22.5 $\mathrm{h} / \mathrm{d}$ (a total of $1.5 \mathrm{~h}$ was dedicated to the cleaning of the system). Cows were granted milking permission after $6 \mathrm{~h}$ from previous milking, unless a milking failure occurred, in which case cows would be granted permission to be milked again immediately. In general, for any particular cow, when the time elapsed since last milking was more than $12 \mathrm{~h}$ during the day, that cow would be fetched and forced to visit the AMS. The milking status of each cow was checked at 0700 , 0900, 1230, and $2030 \mathrm{~h}$ daily. Cows with more than 12 $\mathrm{h}$ since last milking were fetched at these times only.

The treatments were applied to each entire pen following a cross-over design with 2 periods and 2 treatments. Each period lasted 3 mo, with 1 mo of adaptation between the first and the second period. The treatments consisted of the same isocaloric and isonitrogenous ration with 2 levels of concentrate at the AMS. One treatment (low concentrate; LC) consisted of $3 \mathrm{~kg} / \mathrm{d}$ of concentrate and the other of $8 \mathrm{~kg} / \mathrm{d}$ of concentrate (high concentrate; HC). The amount of concentrate delivered by the AMS at each visit was proportional to the time elapsed since last visit and to the maximum concentrate allowance (125 and 333 $\mathrm{g} / \mathrm{h}$ for LC and HC, respectively). For example, a cow in the LC treatment that visited the AMS $8 \mathrm{~h}$ after a first milking would receive $1 \mathrm{~kg}$ of concentrate. Also, concentrate was only offered if the cow lowered its head into the feeder; thus, it was possible for a cow to visit the AMS and not receive any concentrate or just receive half of its allowance because it stopped eating the concentrate offered.

All cows received the same total ration, but a different amount of concentrate from this ration was offered at the AMS depending on treatment (Table 1). The concentrate at the AMS had the same nutrient (19.8\% $\mathrm{CP}, 23.5 \% \mathrm{NDF}, 46.2 \% \mathrm{NFC}, 1.81 \mathrm{Mcal}$ of $\mathrm{NE}_{\mathrm{L}} / \mathrm{kg}$, DM basis) and ingredient (Table 1) composition in both treatments. Cows were fed the basal mixed ration twice daily (to attain a $3 \%$ orts).

\section{Measurements}

Individual eating behavior, including time, number, and duration of visits to the feed troughs, as well as individual feed consumption at each visit were continuously monitored throughout the study using a computerized system (Bach et al., 2004). On a daily basis, a grab sample of fresh TMR and a grab sample of refusals from the previous day were obtained to determine DM content of TMR and refusals. Then, assuming that the moisture loss rate of the TMR throughout the day was constant, each meal consumption was adjusted to the predicted DM content corresponding to the time of the day at which consumption occurred. Also, milking frequency and pattern (time of the day) were recorded during the study. Individual milk production was recorded at each milking by the AMS, and milk composition (fat and protein) was determined monthly at an official laboratory (ALLIC, Cabrils, Spain).

\section{Calculations and Statistical Analyses}

To group consecutive visits to the feed troughs into a single meal, meal criteria (maximum amount of time between visits to the feed troughs to consider a visit as a part of the same meal) were calculated using a model composed of 3 or 2 normal distributions resulting from the natural logarithm of time (in seconds) between feed trough visits as described by Bach et al. (2006).

All data collected daily (intake, yield, feeding behavior, visits to the AMS, etc.) were summarized by week. Data considered in the analysis (including the number of daily meals) were normally distributed. The stage of lactation of each cow was classified as a 4-class ordinal variable using the quartiles of the DIM distribution as cutoffs. Data were analyzed using a mixedeffects linear model that accounted for the random effect of each cow within pen and the fixed categori- 
Table 1. Ingredient and nutrient composition of the experimental diets and the concentrates offered in the basal ration and during automatic milkings

\begin{tabular}{|c|c|c|}
\hline \multirow[b]{2}{*}{ Item } & \multicolumn{2}{|c|}{ Treatment } \\
\hline & $\begin{array}{c}\text { Low } \\
\text { concentrate }\end{array}$ & $\begin{array}{c}\text { High } \\
\text { concentrate }\end{array}$ \\
\hline \multicolumn{3}{|l|}{ Basal ration, \% of total DMI } \\
\hline Corn silage & 13.3 & 13.3 \\
\hline Alfalfa hay & 28.4 & 28.4 \\
\hline Concentrate for the basal ration & 58.6 & 58.6 \\
\hline Amount, $\mathrm{kg}$ as fed/d & 6.5 & 11.5 \\
\hline Whole cottonseed & 31.5 & 17.6 \\
\hline Corn gluten feed & 8.3 & 10.0 \\
\hline Soybean meal 44 & 12.7 & 15.1 \\
\hline Wheat middlings & 2.8 & 3.5 \\
\hline Corn grain, ground & 24.6 & 29.5 \\
\hline Wheat grain, ground & 2.8 & 3.3 \\
\hline Barley grain, ground & 2.8 & 3.3 \\
\hline Soybean hulls & 11.2 & 13.5 \\
\hline Molasses & 0.9 & 0.9 \\
\hline Magnesium oxide & 0.33 & 0.33 \\
\hline Calcium carbonate & 1.3 & 1.6 \\
\hline Sodium chloride & 0.7 & 0.9 \\
\hline Vitamin-mineral premix ${ }^{1}$ & 0.45 & 0.45 \\
\hline \multicolumn{3}{|c|}{ Concentrate for the automatic milking system } \\
\hline Amount offered, kg as fed/d & 3.0 & 8.0 \\
\hline Corn gluten feed & 12.1 & 12.1 \\
\hline Soybean meal 44 & 18.4 & 18.4 \\
\hline Wheat middlings & 4.0 & 4.0 \\
\hline Corn grain, ground & 36.0 & 36.0 \\
\hline Wheat grain, ground & 4.0 & 4.0 \\
\hline Barley grain, ground & 4.0 & 4.0 \\
\hline Soybean hulls & 16.6 & 16.6 \\
\hline Molasses & 1.0 & 1.0 \\
\hline Magnesium oxide & 0.33 & 0.33 \\
\hline Calcium carbonate & 1.8 & 1.8 \\
\hline Sodium chloride & 1.2 & 1.2 \\
\hline Vitamin-mineral premix ${ }^{1}$ & 0.45 & 0.45 \\
\hline \multicolumn{3}{|l|}{ Nutrient composition of total ration } \\
\hline $\mathrm{CP}, \%$ & 16.7 & 16.7 \\
\hline $\mathrm{RDP}, \%$ of $\mathrm{CP}$ & 67.4 & 67.4 \\
\hline $\mathrm{NDF}, \%$ & 33.8 & 33.8 \\
\hline $\mathrm{ADF}, \%$ & 20.3 & 20.3 \\
\hline NFC, \% & 38.3 & 38.3 \\
\hline Net energy, Mcal of $\mathrm{NE}_{\mathrm{L}} / \mathrm{kg}$ & 1.66 & 1.66 \\
\hline
\end{tabular}

${ }^{1}$ Composition: $3,750 \mathrm{kIU} / \mathrm{kg}$ of vitamin A, $750 \mathrm{kIU} / \mathrm{kg}$ of vitamin $\mathrm{D}, 2.5 \mathrm{mg} / \mathrm{kg}$ of vitamin $\mathrm{E}, 2.5 \mathrm{~g} / \mathrm{kg}$ of $\mathrm{Fe}, 12.5 \mathrm{~g} / \mathrm{kg}$ of $\mathrm{Zn}, 1.25 \mathrm{~g} / \mathrm{kg}$ of $\mathrm{Cu}, 10 \mathrm{~g} / \mathrm{kg}$ of $\mathrm{Mn}, 0.1 \mathrm{~g} / \mathrm{kg}$ of $\mathrm{Co}$, and $0.4 \mathrm{~g} / \mathrm{kg}$ of I.

cal effects of sequence, period, level of concentrate, parity (primiparous vs. multiparous), stage of lactation, week, and the 2-way interactions between the level of concentrate and week, stage of lactation, and parity. Week entered the model as a repeated measure using a compound symmetry variance-covariance structure. These statistical analyses were performed with SAS (SAS Institute, 1999). Additionally, a mixed effects Poisson regression model for longitudinal data with cow as a random effect, week within period as a repeated measure, time elapsed between when a cow left the AMS and first visited the feed bunk as depen- dent variable, and level of concentrate ( $\mathrm{LC}$ or $\mathrm{HC}$ ) as the independent variable was performed using Stata (Stata Corporation, 2006). Also, a mixed-effects Poisson regression model for longitudinal data with cow as a random effect, week within period as a repeated measure, time elapsed between when a cow left the AMS and first visited the feed bunk as dependent variable, level of concentrate (LC or HC), whether the cow visited the AMS voluntarily or after being fetched, and the interaction between these 2 variables as independent variables was also performed using Stata (Stata Corporation, 2006). 


\section{(A)}

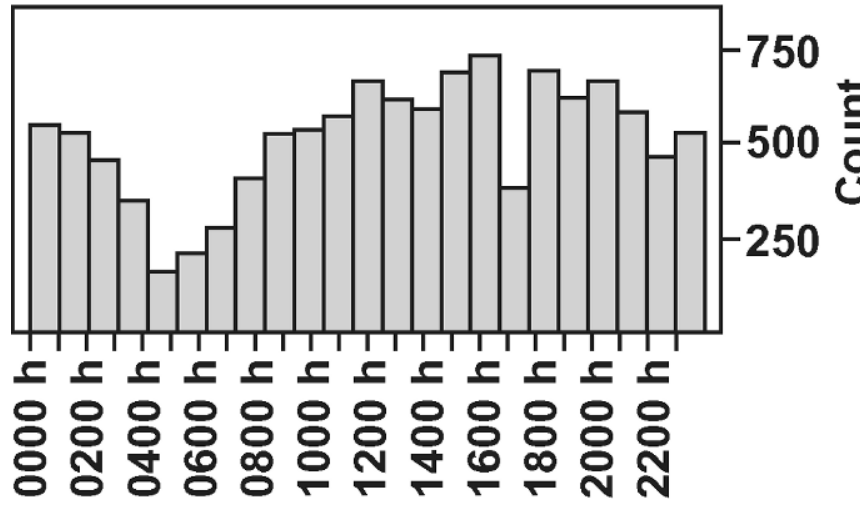

(B)

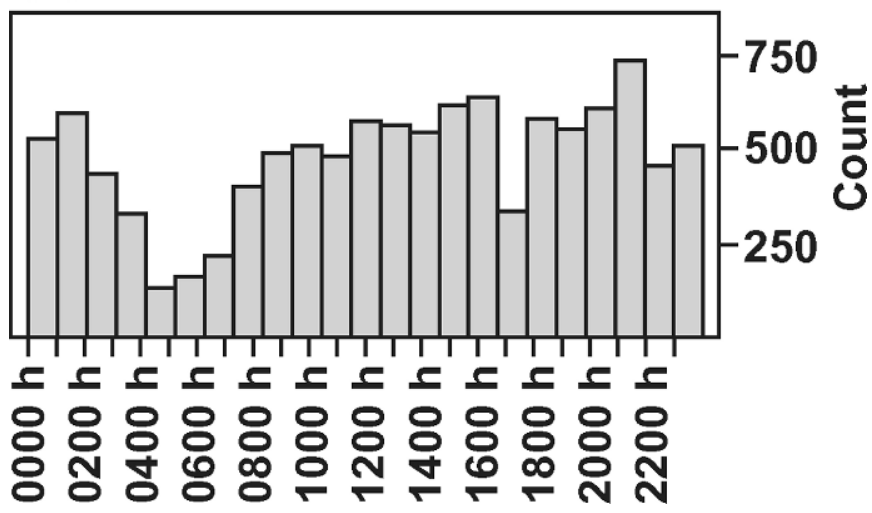

Figure 1. Visit pattern (number of visits/h during the entire study) to the automatic milking system by cows receiving a low concentrate (A) or a high concentrate (B) allowance during milking.

\section{RESULTS AND DISCUSSION}

\section{Milking Attendance and Milk Production}

Cows visited the AMS following a similar pattern in both treatments (Figure 1). The number of cows needed to be fetched daily to the AMS (involuntary milkings) did not differ between LC and HC treatments (Table 2). The proportion of cows that needed to be fetched in this study (0.27) was lower to that reported by Kremer and Ordolff (1992), who found that with an average of 2.8 milkings per day, $45.9 \%$ of the visits were voluntary, and cows had to be fetched over $50 \%$ of the visits. More recently, Rousing et al. (2006) have reported a similar proportion of cows needed to be fetched (0.30) than in the current study. The number of voluntary daily milkings was similar in both treatments, and therefore, the total number of daily milkings did not differ between LC and HC treatments. An earlier study (Prescott et al., 1998) using only 12
Table 2. Number of voluntary, involuntary, and total daily milkings of cows receiving 2 isoenergetic and isonitrogenous rations but with a low (about $3 \mathrm{~kg} / \mathrm{d}$ ) or a high (about $8 \mathrm{~kg} / \mathrm{d}$ ) amount of concentrate at the automatic milking system

\begin{tabular}{lcccc}
\hline & \multicolumn{2}{c}{ Treatment } & & \\
\cline { 2 - 3 } & $\begin{array}{c}\text { Low } \\
\text { concentrate }\end{array}$ & $\begin{array}{c}\text { High } \\
\text { concentrate }\end{array}$ & SE & $P$-value \\
Item & 0.7 & 0.7 & 0.04 & 0.29 \\
Involuntary milkings/d & 1.9 & 2.1 & 0.06 & 0.54 \\
Voluntary milkings/d & 2.6 & 2.8 & 0.07 & 0.13 \\
Total milkings/d & & & & \\
\hline
\end{tabular}

cows concluded that feeding concentrate in the AMS was a stronger motivation than the urge of emptying the udder. More recently, Halachmi et al. (2005) found no differences in milking attendance to an AMS when comparing a daily concentrate allowance at the AMS of $1.5 \mathrm{vs.} 7 \mathrm{~kg} / \mathrm{d}$. Furthermore, Halachmi et al. (2006) reported that the incentive offered by concentrate feeding at an AMS was independent of the starch content of the grain offered, and thus, the opportunity of feeding large amounts of concentrate at the AMS without incurring rumen acidosis seemed plausible. Nevertheless, the evidence in favor of a positive stimulating effect of offering large amounts of concentrate at an AMS does not seem to exist, in agreement with the results of the current study.

To overcome any potential bias on the interpretation of the results because of the relatively large proportion of involuntary milkings observed during the study, the data from cows that were not fetched to the AMS were analyzed separately from the rest of data. Cows that were not fetched and received the LC treatment were milked $2.4 \pm 0.1$ times per day, whereas those receiving the HC treatment were milked $2.7 \pm 0.1$ times per day, with this difference being significant $(P<0.05)$. It could be concluded that concentrate offering did increase milking frequency of those cows that did not need to be fetched to the AMS, but offering a large amount of concentrate in the AMS did not reduce the need to fetch the cows that would not visit the AMS otherwise.

Milk production and milk composition were similar in both treatments (Table 3). Differences in milk production could have been expected if milking frequency had been affected by the concentrate level offered at the AMS, but because milking frequency was the same, the results obtained are logical. Regarding milk production of cows that were not fetched to the AMS, LC cows produced $29.9 \pm 0.9 \mathrm{~kg} / \mathrm{d}$, and $\mathrm{HC}$ cows produced $31.7 \pm 0.9 \mathrm{~kg} / \mathrm{d}$, with this difference being only numerical $(P=0.16)$. As occurred with the rest of cows, milk composition was not affected by the level of concen- 
Table 3. Dry matter intake and milk production of cows receiving 2 isoenergetic and isonitrogenous rations but with a low (about $3 \mathrm{~kg} / \mathrm{d}$ ) or a high (about $8 \mathrm{~kg} / \mathrm{d}$ ) amount of concentrate at the automatic milking system (AMS)

\begin{tabular}{lcccc}
\hline & \multicolumn{2}{c}{ Treatment } & & \\
\cline { 2 - 3 } & $\begin{array}{c}\text { Low } \\
\text { concentrate }\end{array}$ & $\begin{array}{c}\text { High } \\
\text { concentrate }\end{array}$ & $\mathrm{SE}$ & $P$-value \\
\hline Item & 2.6 & 6.8 & 0.02 & $<0.001$ \\
Concentrate at the AMS, kg of DM/d & 19.0 & 14.2 & 0.27 & $<0.001$ \\
Basal ration, kg of DM/d & 21.7 & 21.0 & 0.26 & 0.07 \\
Total DMI, kg/d & 32.8 & 32.1 & 0.89 & 0.92 \\
Milk production, kg/d & 3.66 & 3.64 & 0.02 & 0.45 \\
Milk fat content, \% & 3.23 & 3.28 & 0.02 & 0.13 \\
Milk protein content, \% & & &
\end{tabular}

trate offered at the AMS. Cows receiving the LC treatment had $3.63 \pm 0.04$ and $3.26 \pm 0.03 \%$ milk fat and protein contents, respectively, and HC cows had 3.60 \pm 0.04 and $3.27 \pm 0.03 \%$ milk fat and protein contents, respectively. Therefore, cows that were not fetched responded in a similar manner than the rest of cows and did not increase milk production when receiving large amounts of concentrate in the AMS, although their average daily milking frequency increased.

\section{Feed Intake and Eating Behavior}

The actual concentrate consumption at the AMS was lower than initially planned. Nevertheless, concentrate consumption was greater $(P<0.001)$ when cows were in the HC than in the LC treatment (Table 3), and consequently, the amount of basal ration consumed at the feed bunk was lower $(P<0.001)$ in the HC than in the LC treatment. As a result, total DMI tended $(P=0.07)$ to be lower when cows received the HC treatment than when cows received the LC treatment. Therefore, when the basal ration is high in corn silage, offering high levels of concentrate at the AMS might lower total DMI due to decrease in the consumption of basal ration at the feed bunk. Again, the same pattern was observed on cows that were not fetched to the AMS. The LC cows that were not fetched consumed less $(P<0.001)$ concentrate $(2.6 \pm 0.03 \mathrm{~kg} / \mathrm{d})$ and more $(P<0.01)$ basal ration $(19.1 \pm 1.3 \mathrm{~kg} / \mathrm{d})$ than $\mathrm{HC}$ cows that were never fetched $(6.9 \pm 0.03$ and $14.5 \pm 1.1 \mathrm{~kg} /$ $\mathrm{d}$, respectively). However, there were no differences $(P=0.31)$ in total DMI between the unfetched LC cows $(21.8 \pm 0.5 \mathrm{~kg} / \mathrm{d})$ and the unfetched HC cows $(21.3 \pm$ $0.2 \mathrm{~kg} / \mathrm{d}$ ). The numerical difference in intake between the LC and HC cows that were not fetched followed the same direction of the tendency observed with the rest of cows and could partially explain why milk production of the unfetched cows receiving the HC treatment did not increase as a result of the increased milking frequency.
The deviation of actual concentrate intake from the one designed in the experiment changed slightly the amount of nutrients consumed by cows in both treatments. For instance, CP intake in HC cows was 3.44 $\mathrm{kg} / \mathrm{d}$, whereas it was $3.48 \mathrm{~kg} / \mathrm{d}$ in the LC cows. Similarly, energy consumption was slightly greater in LC cows (34.7 Mcal of $\mathrm{NE}_{\mathrm{L}} / \mathrm{d}$ ) than in $\mathrm{HC}$ cows (34.5 Mcal of $\mathrm{NE}_{\mathrm{L}} / \mathrm{d}$ ).

Despite the difference in the amount of basal ration consumed, cows in both treatments spent the same amount of time consuming the basal ration (Table 4). Thus, the eating rate was slower in $\mathrm{HC}$ than in LC cows (Table 4). Similarly, Robinson and McQueen (1997) also showed that eating rate decreased as the proportion of forage in the TMR increased. In contrast, Maekawa et al. (2002) reported no differences in eating times or eating rates when comparing cows consuming a 50:50 forage:concentrate ration offered as a TMR or with concentrate and forage offered separately. Also,

Table 4. Feeding behavior at the feed troughs of cows receiving 2 isoenergetic and isonitrogenous rations but with a low (about $3 \mathrm{~kg} /$ d) or a high (about $8 \mathrm{~kg} / \mathrm{d}$ ) amount of concentrate at the automatic milking system

\begin{tabular}{|c|c|c|c|c|}
\hline \multirow[b]{2}{*}{ Item } & \multicolumn{2}{|c|}{ Treatment } & \multirow[b]{2}{*}{$\mathrm{SE}$} & \multirow[b]{2}{*}{$P$-value } \\
\hline & $\begin{array}{c}\text { Low } \\
\text { concentrate }\end{array}$ & $\begin{array}{c}\text { High } \\
\text { concentrate }\end{array}$ & & \\
\hline \multicolumn{5}{|l|}{ All cows } \\
\hline Total eating time, ${ }^{1} \mathrm{~min} / \mathrm{d}$ & 167.8 & 175.6 & 5.1 & 0.28 \\
\hline Eating rate, ${ }^{1} \mathrm{~g}$ of $\mathrm{DM} / \mathrm{min}$ & 113.2 & 80.7 & 0.2 & $<0.01$ \\
\hline Number of daily meals/d ${ }^{1}$ & 9.5 & 10.2 & 0.2 & 0.02 \\
\hline Meal duration, min & 17.1 & 17.2 & 0.4 & 0.79 \\
\hline Meal size, $\mathrm{kg}$ of $\mathrm{DM} / \mathrm{meal}$ & 1.9 & 1.4 & 0.1 & $<0.01$ \\
\hline \multicolumn{5}{|l|}{ Unfetched cows } \\
\hline Total eating time ${ }^{1} \mathrm{~min} / \mathrm{d}$ & 167.1 & 177.2 & 6.4 & 0.26 \\
\hline Eating rate, ${ }^{1} \mathrm{~g}$ of $\mathrm{DM} / \mathrm{min}$ & 114.1 & 82.1 & 2.6 & $<0.01$ \\
\hline Number of daily meals/d ${ }^{1}$ & 9.5 & 9.6 & 0.2 & 0.81 \\
\hline Meal duration, min & 17.1 & 18.3 & 0.6 & 0.47 \\
\hline Meal size, $\mathrm{kg}$ of $\mathrm{DM} / \mathrm{meal}$ & 2.0 & 1.6 & 0.1 & 0.01 \\
\hline
\end{tabular}

${ }^{1}$ Does not account for the consumption of concentrate at the automatic milking system. 
the number of daily meals of basal ration was greater $(P<0.05)$ in HC than in LC cows. The amount of basal ration DM consumed at every meal (meal size) was greater $(P<0.05)$ in LC than in HC cows. Meal duration of basal ration consumption was not affected by the level of concentrate offered at the AMS, but it decreased $(P<0.05)$ as DIM increased (from $17.6 \pm$ 0.5 to $16.1 \pm 0.4 \mathrm{~min} / \mathrm{meal}$ at the beginning and at the end of the lactation curve, respectively), and this decrease was more pronounced $(P<0.05)$ when cows were on the $\mathrm{HC}(15.9 \pm 0.3 \mathrm{~min} / \mathrm{meal}$ at the end of the lactation curve) than on the $\mathrm{LC}(16.3 \pm 0.4 \mathrm{~min} / \mathrm{meal}$ at the end of the lactation curve) treatment. When only data from cows that were not fetched were considered, similar results were found. Cows not fetched receiving the LC treatment $(167.1 \pm 6.5 \mathrm{~min} / \mathrm{d})$ spent a similar $(P=0.26)$ amount of time consuming the basal ration as the $\mathrm{HC}$ cows not fetched $(177.2 \pm 6.4 \mathrm{~min} / \mathrm{d})$. The eating rate of unfetched LC cows $(114.1 \pm 2.6 \mathrm{~g}$ of DM/ min) was greater $(P<0.01)$ than that of unfetched $\mathrm{HC}$ cows $(82.1 \pm 2.5 \mathrm{~g}$ of $\mathrm{DM} / \mathrm{min})$. Similarly, meal duration of the LC cows (17.1 $\pm 0.5 \mathrm{~min})$ not fetched was numerically lower $(P=0.47)$ than that of unfetched HC cows $(18.3 \pm 0.7 \mathrm{~min})$. Similarly to what occurred with all cows, the unfetched cows receiving the LC treatment consumed $(2.0 \pm 0.1 \mathrm{~kg}$ of $\mathrm{DM} /$ meal $)$ more $(P<0.05)$ feed with every meal than the $\mathrm{HC}$ cows unfetched (1.6 $\pm 0.1 \mathrm{~kg}$ of $\mathrm{DM} / \mathrm{meal})$. However, different to the observations with all cows, the number of daily meals that the unfetched cows in both the LC and $\mathrm{HC}$ treatments performed $(9.5 \pm 0.2$ meals $/ d)$ was the same $(P=0.81)$. This similar number of daily meals observed in the unfetched LC and $\mathrm{HC}$ cows that were not fetched might indicate that fetching cows interfered with the feeding behavior stimulating the number of daily meals.

The time elapsed since a cow left the AMS and visited the feed bunk to consume the basal ration was $11 \%$ shorter $(P<0.001)$ in LC $(63.1 \pm 1.05 \mathrm{~min})$ than in $\mathrm{HC}(70.9 \pm 1.05 \mathrm{~min})$ cows. This fact, together with the lower-than-expected concentrate intake at the AMS, might suggest that the concentrate allowance for the $\mathrm{HC}$ cows might have exceeded the satiety of the cows, resulting in lower concentrate consumption and a longer lag time before cows consumed the basal ration after eating the concentrate at the AMS. The time elapsed since a cow left the AMS and visited the feed bunk was about $14 \%$ shorter $(P<0.05)$ if the cow had voluntarily visited the AMS $(60.8 \pm 1.5 \mathrm{~min})$ than when the cow was fetched to the AMS $(70.7 \pm 1.2 \mathrm{~min})$. The interaction between fetching and level of concentrate was not significant. Thus, it seems that fetching cows to the AMS changed the behavior of the cow, inducing a visit to the feed bunk, but this visit occurred later than it usually did when cows attended the AMS voluntarily.

\section{CONCLUSIONS}

Fetching cows to the AMS reduces the lag time between the exit from milking and the first visit to the feed bunk, and it may modify the number of daily meals a cow performs. Offering large amounts of concentrate at an AMS does not reduce the need for fetching cows, and it may actually reduce total DM intake.

\section{ACKNOWLEDGMENTS}

We thank Ministerio de Educación y Ciencia for partial funding support to conduct this study through the grant AGL2004-07223-C02-01. We also thank Department d'Universitat Recerca i Societat de la Informació for financial support to build the feed monitoring system. Special thanks to Natàlia Ràfols (Institut de Recerca i Tecnologia Agroalimentáries-Unitat de Remugants) for all her work in this study.

\section{REFERENCES}

Bach, A., and I. Busto. 2005. Effects on milk yield of milking interval regularity and teat cup attachment failures with robotic milking systems. Dairy Res. 72:101-106.

Bach, B., C. Iglesias, and I. Busto. 2004. A computerized system for monitoring feeding behavior and individual feed intake of dairy cattle. J. Dairy Sci. 87:4207-4209.

Bach, A., C. Iglesias, M. Devant, and N. Ràfols. 2006. Performance and feeding behavior of primiparous cows loose housed alone or together with multiparous cows. J. Dairy Sci. 89:337-342.

Erdman, R. A., and M. Varner. 1995. Fixed yield responses to increased milking frequency. J. Dairy Sci. 78:1199-1203.

Halachmi, I., S. Ofir, and J. Miron. 2005. Comparing two concentrate allowances in an automatic milking system. Anim. Sci. 80:339-344.

Halachmi, I., E. Shoshani, R. Solomon, E. Maltz, and J. Miron. 2006. Feeding of pellets rich in digestible neutral detergent fiber to lactating cows in an automatic milking system. J. Dairy Sci. 89:3241-3249.

Hogeveen, H., E. Mathijs, and K. Heemskerk. 2004. Motivations of Dutch farmers to invest in an automatic milking system or a conventional milking parlour. Pages 56-61 Automatic Milking: A Better Understanding. Conf. Proc., Lelystad, the Netherlands. Wageningen Acad. Publ., Wageningen, the Netherlands.

Kremer, J. H., and D. Ordolff. 1992 Experiences with continuous robot milking with regard to milk yield, milk composition and behaviour of cows. Pages 253-260 in The Proceedings of the International Symposium on Prospects for Automatic Milking, Wageningen. EAAP Publ. No. 65. A. H. Ipema, A. C. Lippus, J. H. M. Metz, and W. Rossing, ed. Wageningen Acad. Publ., Wageningen, the Netherlands.

Maekawa, M., K. A. Beauchemin, and D. A. Christensen. 2002. Effect of concentrate level and feeding management on chewing activities, saliva production, and ruminal $\mathrm{pH}$ of lactating dairy cows. J. Dairy Sci. 85:1165-1175.

Prescott, N. B., T. T. Mottram, and A. J. F. Webster. 1998. Relative motivations of dairy cows to be milked or fed in a Y-maze and an automatic milking system. Appl. Anim. Behav. Sci. 57:23-33.

Robinson, P. H., and R. E. McQueen. 1997. Influence of level of concentrate allocation and fermentability of forage fiber on 
chewing behavior and production of dairy cows. J. Dairy Sci. 80:681-691.

Rousing, T., J. H. Badsberg, I. C. Klaas, J. Hindhede, and J. T. Sørensen. 2006. The association between fetching for milking and dairy cows' behaviour at milking, and avoidance of human approach-An on-farm study in herds with automatic milking systems. Livestock Sci. 101:219-227.

SAS System for Windows. Release 8.02. SAS Inst. Inc., Cary, NC.
Speroni, M., G. Pirlo, and S. Lolli. 2006. Effect of automatic milking systems on milk yield in a hot environment. J. Dairy Sci. 89:4687-4693.

Stata Corporation. 2006. Stata/SE 9.2 for Macintosh. Stata Corp., College Station, TX.

Wagner-Storch, A. M., and R. W. Palmer. 2003. Feeding behavior, milking behavior, and milk yields of cows milked in a parlor versus an automatic milking system. J. Dairy Sci. 86:1494-1502. 